\title{
Association between 24-hour urine sodium and potassium excretion and diet quality in six-year-old children: a cross sectional study
}

\author{
Oddny K Kristbjornsdottir ${ }^{1}$, Thorhallur I Halldorsson ${ }^{1,2}$, Inga Thorsdottir ${ }^{1,2}$ and Ingibjorg Gunnarsdottir ${ }^{1,2^{*}}$
}

\begin{abstract}
Background: Limited data is available on sodium $(\mathrm{Na})$ and potassium $(\mathrm{K})$ intake in young children estimated by 24 hour (24h) excretion in urine. The aim was to assess $24 \mathrm{~h}$ urinary excretion of $\mathrm{Na}$ and $\mathrm{K}$ in six-year-old children and its relationship with diet quality.

Methods: The study population was a subsample of a national dietary survey, including six-year-old children living in the greater Reykjavik area $(n=76)$. Three day weighed food records were used to estimate diet quality. Diet quality was defined as adherence to the Icelandic food based dietary guidelines. $\mathrm{Na}$ and $\mathrm{K}$ excretion was analyzed from $24 \mathrm{~h}$ urine collections. PABA check was used to validate completeness of urine collections. The associations between $\mathrm{Na}$ and $\mathrm{K}$ excretion and diet quality were estimated by linear regression, adjusting for gender and energy intake.

Results: Valid urine collections and diet registrations were provided by 58 children. Na and K excretion was, mean (SD), $1.64(0.54) \mathrm{g} \mathrm{Na} / 24 \mathrm{~h}$ (approx. $4.1 \mathrm{~g}$ salt/24h) and $1.22(0.43) \mathrm{g} \mathrm{K} / 24 \mathrm{~h}$. In covariate adjusted models Na excretion decreased by $0.16 \mathrm{~g} \mathrm{Na} / 24 \mathrm{~h}(95 \% \mathrm{Cl}: 0.31,0.06)$ per 1-unit increase in diet quality score (score range: 1-4) while $\mathrm{K}$ excretion was increased by $0.18 \mathrm{~g} \mathrm{~K} / 24 \mathrm{~h}$ ( $95 \% \mathrm{Cl}: 0.06,0.29)$.

Conclusions: Na intake, estimated by $24 \mathrm{~h}$ urinary excretion was on average higher than recommended. Increased diet quality was associated with lower $\mathrm{Na}$ excretion and higher $\mathrm{K}$ excretion in six-year-old children.
\end{abstract}

Keywords: Sodium, Potassium, Children, 24h urinary excretion, Diet quality

\section{Background}

The best method of estimating sodium $(\mathrm{Na})$ and potassium (K) intake is by analyzing 24-hour (24h) $\mathrm{Na}$ and $\mathrm{K}$ excretion in urine [1,2], as the use of dietary surveys and food composition databases for estimating $\mathrm{Na}$ and $\mathrm{K}$ intake may introduce either an over- or underestimation of the actual intake. Studies including $24 \mathrm{~h}$ urine collections for estimation of $\mathrm{Na}$ and $\mathrm{K}$ intake in children are relatively few.

Food based dietary guidelines have been established as a result of studies showing that the overall diet quality rather than specific nutrients protects against chronic diseases in adults [3-5]. The main dietary sources of $\mathrm{K}$ contribute to a healthy diet and are in line with food

\footnotetext{
* Correspondence: ingigun@landspitali.is

'Unit for Nutrition Research, Landspitali-University Hospital, Eiriksgata 29, Reykjavik 101, Iceland

${ }^{2}$ Faculty of Food Science and Nutrition, School of Health Sciences, University of Iceland, Eiriksgata 29, Reykjavik 101, Iceland
}

based dietary guidelines [6-8]. On the other hand, the main dietary sources of $\mathrm{Na}$ in children are considered to be less healthy, including processed meat and fast food dishes $[8,9]$. Tracking of dietary habits from early childhood into adulthood has shown that children with extremely high levels of $\mathrm{Na}$ intake tend to maintain those levels over time [10-12]. Therefore, diet in childhood can be a significant determinant of adult dietary habits even after several decades [13].

The aim of the present study was to gather information about $\mathrm{Na}$ and $\mathrm{K}$ intake in six-year-old children by $24 \mathrm{~h}$ urinary excretion. The aim was also to assess the relationship between $\mathrm{Na}$ and $\mathrm{K}$ excretion and diet quality.

\section{Methods}

\section{Subjects}

The source population were subjects invited to participate in a longitudinal study on nutrition and health of

\section{Biomed Central}


Icelandic six-year-olds who had previously participated in studies on nutrition and health during infancy [14] or at two years of age [15]. Originally, families of 180 infants from four maternity wards around Iceland were invited to participate in the infant study and 130 twoyear-old children were randomly selected by the Icelandic National Registry. In the infant study 138 agreed to participate, 27 were lost in follow-up at 12 months of age leaving 111 eligible subjects for the follow up at six years. From the study on two year olds 69 were eligible for the follow-up study at the age of six years, altogether 180 subjects. Each family was contacted by telephone and invited to take part in the study. If consent was obtained, an introductory letter explaining the details of the study was sent by mail. The study was approved by the Local Ethical Committee at Landspitali-University Hospital in Iceland, The National Bioethics Committee and by Icelandic Data Protection Commission. The participation rate in the follow-up study was $73 \%$ where 131 completed three day food records [16]. Only children who were living in the greater Reykjavík area were invited to provide $24 \mathrm{~h}$ urine collections $(\mathrm{n}=111)$ due to practical reasons (i.e. closeness to the study centre), of which 79 agreed. Three of the children providing $24 \mathrm{~h}$ urine collections returned incomplete food records, resulting in 76 subjects eligible for the present analysis.

\section{Weighed food records}

Parents kept weighed food records for their children for three consecutive days including one weekend day and 2 week days using a kitchen scale (PHILIPS HR 2385, Austria) around the time of the child's sixth birthday. Each family received a booklet with which to record all food eaten during this time period. Parents were instructed on how to use the scales and to record the date and time of the meals, specifically to record the brand name or type of food, to include recipes of homemade dishes, and record all drinks and vitamin intake. The data was entered into an interview-based nutrient calculating program, ICEFOOD, designed for the national dietary survey of The Icelandic Nutrition Council [17]. Nutrient losses due to food preparation were included in the calculations. This program included 452 food codes or recipes from the Icelandic Nutrition Council, based on 394 food items from the National Nutrition Database, ISGEM.

\section{$\mathrm{Na}$ and $\mathrm{K}$ excretion}

Parents and caretakers were given both verbal and written instructions in assisting children to collect a $24 \mathrm{~h}$ urine sample on one of the three days of food recording. Each child was provided with a urine collection bottle, a backpack in which to carry the jug and three $80 \mathrm{mg}$ PABA tablets (PABA check, The royal veterinary and agricultural pharmacy, Cophenhagen). On the first morning of the urine collections, instructions were given to discard the first specimen, and from then on to collect all specimens for up to $24 \mathrm{~h}$, up to and including the first specimen the following day. Subjects were asked to take three $80 \mathrm{mg}$ PABA tablets, one tablet during each main meal on the same day as the urine collections. On return to the laboratory, urine volume was recorded. PABA check [18] was used to validate completeness of urine collections. Collections that contained $85 \%$ or more of the PABA ingested were considered complete [19]. Recovery between $50 \%$ and $85 \%$ was adjusted according to a formula developed by Johansson and Bingham 1999 [20]: Na excretion = excretion $[\mathrm{mg} /$ day $]+$ $(0.82 *$ (93-PABA recov) and $\mathrm{K}$ excretion = excretion $[\mathrm{mg} /$ day $]+(0.60 *(93-\mathrm{PABA}$ recov $))$.

$\mathrm{Na}$ and $\mathrm{K}$ concentration was measured immediately by flame emission photometry [21] at Landspitali University Hospital. The remainder of the samples were stored at $-20^{\circ} \mathrm{C}$ for later analysis of PABA which was measured colorimetrically at Forskningsinstitut for Human Ernæring in Cophenhagen, Denmark [22].

\section{Diet quality}

Adherence to the Icelandic food based dietary guidelines (FBDG) was used to assess diet quality score. Portion sizes used to determine diet quality score were adjusted to reflect the $20 \%$ lower energy needs of six-year-olds compared to an adult [23]. The FBDG are based on six recommendations.: $\geq 400 \mathrm{~g}$ fruits and vegetables, $\geq 34 \mathrm{~g}$ fish, $\geq 5 \mathrm{~g}$ fish liver oil and $\geq 400 \mathrm{~g}$ milk and milk products (or $200 \mathrm{~g}$ milk and milk products and $20 \mathrm{~g}$ cheese). The Public Health Institute of Iceland [6] recommends $\mathrm{K}$ intake $\geq 2 \mathrm{~g} / \mathrm{d}$ for children 6-9 year old and the Nordic Nutrition Recommendations [24] $\leq 0.5$ g salt/1000 kJ $(0.5 \mathrm{~g} \mathrm{salt} / 239 \mathrm{kcal})$ for children $2-18$ years old, corresponding to about $3.2 \mathrm{~g}$ salt daily (according to energy intake of $1530 \mathrm{kcal} / \mathrm{d}$ in the present study). Fiber consumption of at least $11 \mathrm{~g} /$ day was used in the evaluation of diet quality score as an indicator of whole grain cereals [25]. One point was obtained by following each guideline, for a maximum of six points. Diet quality score was divided into four groups based on adherence to FBDG, those following one, two, three or at least four of the dietary guidelines.

\section{Anthropometrics}

Height and weight of study participants were measured at Landspitali - Children's Hospital. Subjects wore light weight clothing and no shoes. Height was measured to the nearest $0.1 \mathrm{~cm}$ using a ulmer stadiometer, Busse design (Nersinger Straße 18, 89275 Elchingen, Germany), and weight was measured to the nearest $0.05 \mathrm{~kg}$ using a 
Taniter BWB-620 electronic scale (2625 South Clearbrook Drive, Arlington Height, Illinois 60005, USA).

\section{Statistical analysis}

Statistical analyses were conducted using SPSS for Windows, version 17 (SPSS Inc, Chicago). Descriptive analyses (mean and standard deviation) were used to describe the characteristics of study participants. A visual inspection of histograms suggested that $\mathrm{Na}$ and $\mathrm{K}$ urinary excretion was normally distributed. Independent samples $t$-test was used to test the difference between boys and girls and to determine whether $\mathrm{Na}$ and $\mathrm{K}$ excretion was significantly different between those who follow each food based dietary guideline and those who do not.

To examine the association between diet quality score and $\mathrm{Na}$ and $\mathrm{K}$ excretion we used multivariate linear regression analyses where gender and energy intake were included as covariates. We included gender as a covariate to account for potential sex dependent differences in behavioral and physiological factors. Total energy intake was included as those with high intake were more likely to meet the food based dietary recommendations (as cutoffs in grams/day were used), while simultaneously having higher intakes of $\mathrm{Na}$ and $\mathrm{K}$.

\section{Results}

Of 76 children returning the $24 \mathrm{~h}$ urine collection and also had complete dietary data, 18 were excluded due to incomplete urine collections according to PABA recovery. More than $85 \%$ of the PABA was retrieved in the urine collections of 28 subjects, while excretion from 48 subjects was adjusted (PABA recovery between 50\% and $85 \%)$. Characteristics of the subjects $(n=58)$, and information on $\mathrm{Na}$ and $\mathrm{K}$ excretion is shown in Table 1. The average $\mathrm{Na}$ excretion was $1.66 \mathrm{~g} / 24 \mathrm{~h}$, corresponding to $4.16 \mathrm{~g} \mathrm{NaCl}$ (table salt). Less than one third (29\%) had $\mathrm{Na}$ excretion corresponding to an intake below the recommended salt intake of $3.20 \mathrm{~g} / \mathrm{d}$ [24]. The average $\mathrm{K}$ excretion was $1.21 \mathrm{~g} / 24 \mathrm{~h}$. No significant gender difference was observed. Based on the three-day food records, mean $\mathrm{Na}$ intake was $1.94 \mathrm{~g} /$ day (4.86 g table salt/day) and mean $\mathrm{K}$ intake was $1.91 \mathrm{~g} /$ day. Cereals were found to provide $43 \%$ of the total $\mathrm{Na}$ in the diet, spices $17 \%$, dairy products provided $15 \%$, meat $11 \%$ and $14 \%$ came from other sources. Dairy products (32\%), fruits and vegetables $(22 \%)$ and cereals $(15 \%)$ where found to be the main dietary sources of $\mathrm{K}$.

Table 2 shows the proportion of children meeting each of the guidelines used to estimate the diet quality index. Greatest adherence was found for dairy products and fish where $61 \%$ and $41 \%$ of the children, respectively, had consumption in line with the recommendations. Children who consumed dairy products and dietary fiber
Table 1 Characteristics of study participants

\begin{tabular}{ll}
\hline & $\mathbf{N}=\mathbf{5 8}$ (52\% boys) \\
\hline Age, months (sd) & $72(1.0)$ \\
Height, $\mathrm{cm}(\mathrm{sd})$ & $119(4.6)$ \\
Weight, $\mathrm{kg}(\mathrm{sd})$ & $23(3.1)$ \\
Systolic blood pressure, $\mathrm{mmHg}(\mathrm{sd})$ & $110(11.1)$ \\
Diastolic blood pressure, $\mathrm{mmHg}(\mathrm{sd})$ & $64(11)$ \\
Urine volume, $\mathrm{mL} / 24 \mathrm{~h}(\mathrm{sd})$ & $648(284)$ \\
$\mathbf{N a}$ excretion & \\
$\mathrm{mmol} / 24 \mathrm{~h}(\mathrm{sd})$ & $71(23)$ \\
$\mathrm{mmol} / \mathrm{L}(\mathrm{sd})$ & $120(44)$ \\
$\mathrm{g} / 24 \mathrm{~h}^{1}(\mathrm{sd})$ & $1.64(0.54)$ \\
$\mathrm{g} / \mathrm{kg} / 24 \mathrm{~h}(\mathrm{sd})$ & $0.07(0.02)$ \\
$\mathbf{K}$ excretion & \\
$\mathrm{mmol} / 24 \mathrm{~h}(\mathrm{sd})$ & $31(11)$ \\
$\mathrm{mmol} / \mathrm{L}(\mathrm{sd})$ & $52(20)$ \\
$\mathrm{g} / 24 \mathrm{~h}^{2}(\mathrm{sd})$ & $1.22(0.43)$ \\
$\mathrm{g} / \mathrm{kg} / 24 \mathrm{~h}$ & $0.05(0.02)$ \\
$\mathrm{Na} / \mathrm{K}$ excretion & $1.6(1.3)$ \\
\hline
\end{tabular}

${ }^{1} \mathrm{Na}$ excretion corrected for PABA $=$ excretion in $\mathrm{mg} /$ day $+(0.82 *(93-\mathrm{PABA}$ recov)) [20].

${ }^{2} \mathrm{~K}$ excretion corrected for PABA $=$ excretion in $\mathrm{mg} /$ day $+\left(0.60^{*}(93-\mathrm{PABA}\right.$ recov)) [20].

in line with the recommendations had significantly greater $K$ excretion than those who did not meet the recommendations $(\mathrm{p}=0.01)$ and $(\mathrm{p}=0.02)$, respectively.

The average $\mathrm{Na}$ and $\mathrm{K}$ excretion according to diet quality score is shown in Table 3 . In covariate adjusted models $\mathrm{Na}$ excretion decreased by $0.16 \mathrm{~g} \mathrm{Na} / 24 \mathrm{~h}$ (95\% CI: 0.31 ; 0.06$)$ per 1 -unit increase in diet quality score (score range: $1-4$ ) while $\mathrm{K}$ excretion was increased by $0.18 \mathrm{~g} \mathrm{~K} / 24 \mathrm{~h}$ (95\% CI: 0.06; 0.29). Excluding the salt recommendation from the definition of diet quality did not change the findings.

\section{Discussions}

In the present study $\mathrm{Na}$ and $\mathrm{K}$ excretion were associated with diet quality among six-year-old children. Na excretion in this study of six-year-old children was $1.66 \mathrm{~g} / 24 \mathrm{~h}$ $(0.07 \mathrm{~g} / \mathrm{kg} / 24 \mathrm{~h})$, that corresponds to about 4.2 grams table salt. The average consumption of salt worldwide is generally high, particularly in industrialized countries, and the results from the present study are in line with previous findings [26-28]. In the Nordic nutrition recommendations from 2004 [24] $\leq 0.5 \mathrm{~g}$ salt is recommended per $1000 \mathrm{~kJ}(0.5 \mathrm{~g}$ salt $/ 239 \mathrm{kcal})$ for children 2-18 years old. The average energy intake in the present study was $1530 \mathrm{kcal} /$ day, so the average salt intake should have been close to or below $3.2 \mathrm{~g}$ salt daily. Less than one third (29\%) of the children in the present study had $\mathrm{Na}$ intake in line with the recommendation [24]. Na 
Table $2 \mathrm{Na}$ and $\mathrm{K}$ excretion (g/24h) according to adherence to food based dietary guidelines [6]

\begin{tabular}{|c|c|c|c|c|c|c|}
\hline & \multirow[t]{2}{*}{ Recommendation } & \multirow{2}{*}{$\begin{array}{l}\text { Children follow } \\
(n=58 \text { [n (\%)] }\end{array}$} & \multicolumn{2}{|c|}{$\mathrm{Na}$ excretion (Mean (sd)) } & \multicolumn{2}{|c|}{ K excretion (Mean (sd)) } \\
\hline & & & $\begin{array}{l}\text { Following } \\
\text { FBDG }\end{array}$ & $\begin{array}{l}\text { Not following } \\
\text { FBDG }\end{array}$ & $\begin{array}{l}\text { Following } \\
\text { FBDG }\end{array}$ & $\begin{array}{l}\text { Not following } \\
\text { FBDG }\end{array}$ \\
\hline Fruits and vegetables & $\geq 400 \mathrm{~g} / \mathrm{d}^{1}$ & $5(8.5)$ & $1.89(0.99)$ & $1.62(0.48)$ & $1.44(0.33)$ & $1.19(0.43)$ \\
\hline Fish & $\geq 34 \mathrm{~g} / \mathrm{d}^{1}$ & $24(40.7)$ & $1.60(0.51)$ & $1.68(0.56)$ & $1.34(0.52)$ & $1.12(0.34)$ \\
\hline Fish liver oil & $\geq 5 \mathrm{~g} / \mathrm{d}^{1}$ & $9(15.3)$ & $1.84(0.62)$ & $1.61(0.52)$ & $1.12(0.38)$ & $1.23(0.44)$ \\
\hline Dairy products & $\geq$ two servings $/ d^{1}$ & $36(61.0)$ & $1.65(0.62)$ & $1.65(0.39)$ & $1.32(0.46)$ & $1.04(0.32)^{4}$ \\
\hline Fibre & $\geq 11 \mathrm{~g} / \mathrm{d}^{2}$ & $22(37.3)$ & $1.59(0.49)$ & $1.67(0.56)$ & $1.38(0.48)$ & $1.12(0.36)^{4}$ \\
\hline Salt & $\leq 3.2 \mathrm{~g} / \mathrm{d}^{3}$ & $17(28.8)$ & $1.11(0.18)$ & $1.88(0.48)^{5}$ & $1.33(0.48)$ & $1.16(0.40)$ \\
\hline
\end{tabular}

sd: Standard Deviation.

${ }^{1}$ [6] adjusted according to [23].

2 [25].

${ }^{3}[24]$.

${ }_{5}^{4} p<0.05$ between following FBDG and not following FBDG.

${ }^{5} \mathrm{p}<0.01$ between following and not following FBDG.

is part of various additives and hence added to most foods, either by the industry or in cooking. The high $\mathrm{Na}$ intake observed in this population is of concern and should be recognized by health authorities. In the population studied lower content of salt in cereals (including bread) could significantly contribute to lower $\mathrm{Na}$ intake as this food group provided $43 \%$ of the total $\mathrm{Na}$ consumed. A reduced salt intake of $42 \%$ (IQR: $7 \%-58 \%$ ) was found to be associated with $1.17 \mathrm{mmHg}$ decrease in systolic (95\% CI: -1.78 to $-0.56 ; \mathrm{p}<0.01)$ and $1.29 \mathrm{mmHg}$ diastolic $(95 \% \mathrm{CI}$ -1.94 to $-0.65, \mathrm{p}<0.01)$ blood pressure in a meta analysis including children with mean age of 13 years [29]. From a population viewpoint, a reduction in $\mathrm{BP}$ of $1.1 \mathrm{mmHg}$ in this age group would have major effects of preventing cardiovascular disease in the future [29].

$\mathrm{K}$ excretion in the present study was $1.21 \mathrm{~g} / 24 \mathrm{~h}$ or $0.05 \mathrm{~g} / \mathrm{kg} / 24 \mathrm{~h}$. Few studies exist on $\mathrm{K}$ excretion but two studies examined 8-9 year old children and reported excretion of about $1.80 \mathrm{~g} / 24 \mathrm{~h}$ [28] and $2.00 \mathrm{~g} / 24 \mathrm{~h}$ $(0.07 \mathrm{~g} / \mathrm{kg} / 24 \mathrm{~h})$ [30]. Another study on $3-5$ year old children showed $\mathrm{K}$ excretion of $1.00 \mathrm{~g} / 24 \mathrm{~h}$ or $0.05 \mathrm{~g} / \mathrm{kg} / 24 \mathrm{~h}$ [27]. It is often challenging to compare values from studies on children, mainly due to the different ages and body weights of the young subjects. To ease the comparison, it might be convenient to use the per kilogram approach. $\mathrm{K}$ excretion was associated with many of the components of the diet quality index used in the present study, such as dairy and whole grain (fiber). K excretion appeared to be higher among those children following the recommendations on fruit and vegetable intake, but the number of subjects following the recommendations was too few to draw any meaningful conclusions. This is consistent with previous studies of low fruit and vegetable consumption of Icelandic children, which is lower than in many other European countries [23].

A linear trend was observed between decreased $\mathrm{Na}$ and increased $\mathrm{K}$ excretion and increased adherence to diet quality in the current study. Only a few studies have assessed the association between diet quality and excretion of $\mathrm{Na}$ or $\mathrm{K}$ and none of them included children. $\mathrm{K}$ excretion was found to be associated with diet quality in a study of adults with kidney stones $(\mathrm{r}=0.23, \mathrm{p}<0.01)$ [31]. The recommended food score was used as an index of healthy diet, which contained food groups such as vegetables, fruits, whole grains, low fat dairy, fish and poultry, similar to the present study. Adult nephrolithiasis patients from the Health Professionals Follow-up Study and the Nurses' Health Studies (NHS) I and II collected 24h urine samples and semiquantitative food frequency questionnaires. In the Dietary Approaches to Stop Hypertension (DASH) trial, a dietary DASH score was given based on seven components: high intake of

Table 3 Mean (sd) excretion of $\mathrm{Na}$ and $\mathrm{K}(\mathrm{g} / 24 \mathrm{~h})$ in urine and $\mathrm{Na} / \mathrm{K}$ ratio according to diet quality and the association between diet quality and excretion

\begin{tabular}{|c|c|c|c|c|c|c|c|c|}
\hline & \multicolumn{4}{|c|}{ Diet quality score ${ }^{1}$} & \multirow[b]{2}{*}{ Unadjusted } & \multirow{3}{*}{$\mathrm{p}$} & \multirow[b]{2}{*}{ Adjusted $^{2}$} & \multirow[b]{2}{*}{ p } \\
\hline & 1 & 2 & 3 & 4 & & & & \\
\hline & $(n=13)$ & $(n=24)$ & $(n=10)$ & $(n=11)$ & B $(95 \% \mathrm{Cl})$ & & B $(95 \% \mathrm{Cl})$ & \\
\hline $\mathrm{Na}$ (sodium) & $1.70(0.35)$ & $1.75(0.73)$ & $1.45(0.27)$ & $1.45(0.87)$ & $-0.10(-0.25 ; 0.04)$ & 0.06 & $-0.16(-0.31 ;-0.06)$ & 0.03 \\
\hline K (potassium) & $1.09(0.29)$ & $1.08(0.39)$ & $1.51(0.55)$ & $1.59(0.29)$ & $0.19(0.08 ; 0.29)$ & $<0.01$ & $0.18(0.06 ; 0.29)$ & $<0.01$ \\
\hline $\mathrm{Na} / \mathrm{K}$ ratio & $1.7(0.6)$ & $2.1(2.1)$ & $1.1(0.4)$ & $1.0(0.7)$ & $-0.25(-0.60 ; 0.10)$ & 0.07 & $-0.28(-0.66 ; 0.11)$ & 0.06 \\
\hline
\end{tabular}

${ }^{1}$ Follows one of the FBDG; 2: Follows two of the FBDG; 3: Follow three of the FBDG; 4: Follows at least four of the FBDG. [6,23-25].

${ }^{2}$ Adjusted for gender and energy intake. 
fruits, vegetables, nuts and legumes, dairy products, and whole grains and low intake of sweetened beverages and red and processed meats. It was found that higher DASH scores were associated with higher $\mathrm{K}$ in all three cohorts ( $P$ for trend all $\leq 0.01)$ [32]. In 12 healthy adults, a two-week long elimination of fruits and vegetables from the diet resulted in a decrease in urinary $\mathrm{K}$ of $62 \%$ $(\mathrm{p}<0.05)$, assessed from 24h urine collection [32].

\section{Strength and limitations}

The strength of the study is an accurate food record for three days and a valid $24 \mathrm{~h}$ urine sample. The fact that we only had one $24 \mathrm{~h}$ urine excretion per individual might be considered a limitation as more than one collection is needed for individual assessment of $\mathrm{Na}$ and $\mathrm{K}$ excretion. However, in the present analysis the $\mathrm{Na}$ and $\mathrm{K}$ excretion measurements were used on group level according to adherence to food based recommendations. Furthermore, the $\mathrm{Na}$ and $\mathrm{K}$ intake estimated by the food records are also presented in this report, providing additional information. The urine collections were conducted on one of the three days of food recording and $\mathrm{Na}$ and $\mathrm{K}$ excretion is known to be an indicator of recent consumption.

\section{Conclusions}

$\mathrm{Na}$ intake estimated by $24 \mathrm{~h}$ urine excretion was, on average, higher than recommended. Increased diet quality was associated with lower $\mathrm{Na}$ excretion and higher $\mathrm{K}$ excretion in six-year-old children.

\section{Abbreviations}

24h: 24-hour; K: Potassium; Na: Sodium; FBDG: Food based dietary guidelines.

\section{Competing interests}

The authors declare that they have no competing interests.

\section{Authors' contributions}

IT and IG contributed to design, data collection, interpretation and final writing of the paper. TIH contributed statistical analysis, interpretation and final writing. OKK contributed handling/management, statistical analysis, interpretation and wrote the first draft of the manuscript. All authors read and approved the final manuscript.

\section{Acknowledgements}

The authors thank the families who participated in the study, Margaret Ospina for data collection in the study of 6-year-olds and the staff of the laboratories at Landspitali University hospital in Reykjavík for their involvement. Also Hildur Atladóttir and Björn Gunnarsson for their valuable work.

This work was supported by The Research Fund of the University of Iceland. The data collection was supported by The Icelandic Center for Research.

Received: 15 June 2012 Accepted: 25 October 2012

Published: 15 November 2012

\section{References}

1. Margetts BM, Nelson M: Design concepts in nutritional epidemiology. secondth edition. New York: Oxford University Press; 1997.
2. Bingham SA: The dietary assessment of individuals; methods, accuracy, new techniques and recommendations. Nutrition abstract review 1987, 57(10):705-741.

3. Kant AK: Dietary patterns and health outcomes. J Am Diet Assoc 2004, 104(4):615-635.

4. Knoops KT, et al: Mediterranean diet, lifestyle factors, and 10-year mortality in elderly European men and women: the HALE project. JAMA 2004, 292(12):1433-1439.

5. Trichopoulou A, et al: Adherence to a Mediterranean diet and survival in a Greek population. N Engl J Med 2003, 348(26):2599-2608.

6. The Public Health Institute of Iceland: Recommendations on diet and nutrients for adults and children from 2 years of age (in Icelandic); 2006. http://www.lydheilsustod.is/media/manneldi/utgefid//mataraedi-lowres.pdt.

7. ISGEM: The Icelandic Food Composition Database; 2009. http://www.matis.is/ ISGEM/en/.

8. Meneton $P$, et al: Dietary sources and correlates of sodium and potassium intakes in the French general population. Eur J Clin Nutr 2009, 63(10):1169-1175.

9. Heino T, et al: Sodium intake of 1 to 5 -year-old children: the STRIP project. The Special Turku Coronary Risk Factor Intervention Project. Acta Paediatr 2000, 89(4):406-410.

10. Patterson $\mathrm{E}$, et al: The tracking of dietary intakes of children and adolescents in Sweden over six years: the European Youth Heart Study. Int J Behav Nutr Phys Act 2009, 6:91.

11. Lake $A A$, et al: Longitudinal change in food habits between adolescence (11-12 years) and adulthood (32-33 years): the ASH30 Study. J Public Health (Oxf) 2006, 28(1):10-16.

12. Singer $M R$, et al: The tracking of nutrient intake in young children: the Framingham Children's Study. Am J Public Health 1995, 85(12):1673-1677.

13. Mikkila $V$, et al: Longitudinal changes in diet from childhood into adulthood with respect to risk of cardiovascular diseases: The Cardiovascular Risk in Young Finns Study. Eur J Clin Nutr 2004, 58(7):1038-1045.

14. Atladottir $\mathrm{H}$, Thorsdottir l: Energy intake and growth of infants in Icelanda population with high frequency of breast-feeding and high birth weight. Eur J Clin Nutr 2000, 54(9):695-701.

15. Gunnarsson BS, Thorsdottir I, Palsson G: Iron status in 6-y-old children: associations with growth and earlier iron status. Eur J Clin Nutr 2005, 59(6):761-767

16. Gunnarsson BS, Thorsdottir I, Palsson G: Associations of iron status with dietary and other factors in 6-year-old children. Eur J Clin Nutr 2007, 61(3):398-403.

17. Steingrimsdottir L, Thorgeirsdottir H, Olafsdottir A: The Diet of Icelanders. Dietary survey of the Icelandic nutrition council 2002. Main findings: The Public Health Institute of Iceland; 2003.

18. Bingham SA, et al: Reference values for analytes of 24-h urine collections known to be complete. Ann Clin Biochem 1988, 25(Pt 6):610-619.

19. Bingham SA, et al: Validation of dietary assessment methods in the UK arm of EPIC using weighed records, and 24-hour urinary nitrogen and potassium and serum vitamin C and carotenoids as biomarkers. Int J Epidemiol 1997, 26(Suppl 1):S137-S151.

20. Johansson G, Bingham S, Vahter M: A method to compensate for incomplete 24-hour urine collections in nutritional epidemiology studies. Public Health Nutr 1999, 2(4):587-591.

21. Kaplan LA, Pesce AJ: Operator's manual IL 943 Flame Photometer. Instrumentation Laboratory, in: Clinical Chemistry: Theory, analysis, and correlation, Volume 2. St. Louis: The C.V. Mosby Company; 1989.

22. Bingham S, Cummings JH: The use of 4-aminobenzoic acid as a marker to validate the completeness of $24 \mathrm{~h}$ urine collections in man. Clin Sci (Lond) 1983, 64(6):629-635.

23. Kristjansdottir AG, Thorsdottir I: Adherence to food-based dietary guidelines and evaluation of nutrient intake in 7-year-old children. Public Health Nutr 2009, 12(11):1999-2008.

24. Nordic nutrition recommendation 2004. Integrating nutrition and physical activity. 4th edition. Copenhagen: Nord 2004:13. Nordic Council of Ministers; 2004.

25. Williams $\mathrm{CL}$, Bollella $\mathrm{M}$, Wynder EL: A new recommendation for dietary fiber in childhood. Pediatrics 1995, 96(5 Pt 2):985-988.

26. Alexy $U$, et al: 4 h-Sodium excretion and hydration status in children and adolescents - Results of the DONALD Study. Clin Nutr 2012, 31(1):78-84. Epub 2011 Sep 16. 
27. Allison ME, Walker $\mathrm{V}$ : The sodium and potassium intake of 3 to 5 year olds. Arch Dis Child 1986, 61(2):159-163.

28. Knuiman JT, et al: Blood pressure and excretion of sodium, potassium, calcium and magnesium in 8- and 9-year old boys from 19 European centres. Eur J Clin Nutr 1988, 42(10):847-855.

29. He FJ, MacGregor GA: Importance of salt in determining blood pressure in children: meta-analysis of controlled trials. Hypertension 2006, 48(5):861-869.

30. Zwiauer K, Eberlein G, Widhalm K: Inverse relationship between diastolic blood pressure and urinary excretion of potassium in girls aged 8 to 9 years-a preliminary communication. Wien Klin Wochenschr 1991, 103(17):519-523.

31. Mente A, et al: Urinary potassium is a clinically useful test to detect a poor quality diet. J Nutr 2009, 139(4):743-749.

32. Taylor EN, et al: DASH-style diet and 24-hour urine composition. Clin J Am Soc Nephrol 2010, 5(12):2315-2322.

doi:10.1186/1475-2891-11-94

Cite this article as: Kristbjornsdottir et al: Association between 24-hour urine sodium and potassium excretion and diet quality in six-year-old children: a cross sectional study. Nutrition Journal 2012 11:94.

\section{Submit your next manuscript to BioMed Central and take full advantage of:}

- Convenient online submission

- Thorough peer review

- No space constraints or color figure charges

- Immediate publication on acceptance

- Inclusion in PubMed, CAS, Scopus and Google Scholar

- Research which is freely available for redistribution 